\title{
HISTOLOGICAL AND EXPERIMENTAL OBSERVATIONS ON THE DESTRUCTION OF TUMOUR CELLS IN THE BLOOD VESSELS. ${ }^{1}$
}

\author{
By Dr. Tokumatsu Iwasaki. \\ From the Department of Pathology, University of Edinburgh.
}

(Plates VII.-IX.)

THE fact that the organism has power to protect itself against several noxæ, especially micro-organisms, by means of a local or general reaction, is well known. Such processes are found also in malignant tumours; many authors have reported natural healing of these.

Orth (1904 $\left.{ }^{1}\right)$ noticed in three cases of epithelioma the destruction of tumour cells by giant cells and young connective tissue, and substitution by. the latter; the condition was essentially the same as the reaction against a foreign body. Handley $\left(1906^{2}\right)$ tells us in his work, that when carcinoma cells in lymphatic vessels grow too voluminous and expand the vessel walls, the pressure of the tumour causes a local inflammation in the surrounding area and granulation tissue develops, destroys the tumour content, and converts it into a fibrous cord. Further, Petersen and Colmers $\left(1902-04{ }^{3}\right)$ report a case of pyloric carcinoma, diagnosed microscopically, with metastases in the lymphatic glands of the curvatures, ligamentum gastroduodenale, and in the head of the pancreas. This healed after a partial operation, and at the laparotomy, done two and a half years later, there was no tumour to be seen ; moreover, this was definitely proved by the dissection which was made at the post-mortem examination six months later. Senger $\left(1894^{4}\right)$ described a similar case.

Natural healing occurs more frequently in malignant chorion-epithelioma, even after it has formed metastases in the lung-Riesel $\left(1903^{5}\right)$, Michel $\left(1909^{6}\right)$, Teacher (1907-87), etc. This takes place by the abnormal proliferation of connective tissue and encapsulation. Teacher attributes a very important rôle to hæmorrhage in the destruction of this tumour; the effused blood, by pressing on and enclosing the masses of tumour cells within the growing margin, interferes with their vitality. Possibly part of the effect may be due to the deleterious influence of the blood on the tumour cells. The same observation has been made in animal tumours-Sticker $\left(1909^{8}\right)$. Then, again, the therapentic action of $\mathrm{X}$-ray and radium on malignant growths is due to encapsulation and substitution of the tumour by connective tissue.

On the other hand, there are interesting observations on the destruction of tumour cells in blood vessels. Many years ago it was suggested that the passing of tumour cells into the blood stream from the primary growth does

1 Received August 21, 1915.

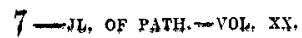


not necessarily cause metastases. Goldmann (1897 ${ }^{\circ}$ ), who first enunciated this opinion, found that in some cases of carcinoma where the vein systems are severely involved, the organs may remain entirely free from metastases, and came to the conclusion that there must exist in the body some self-protecting substance. Petersen and Colmers hold that the first carcinoma cells that pass into the blood from the primary nodule, die, and only when an organ is sufficiently charged with the products of decomposed masses of these cells can new metastases colonise and develop further. Lomer $\left(1883^{10}\right)$ expressed a similar opinion: "If we consider the fact that carcinomata do not always form metastases, although they send out the cells into lymphatics, we must conclude that the tumour cells which were carried away by lymph have been absorbed and destroyed, and only when the normal absorbing ability of the body is disturbed, do the tumour cells settle in the organs and proliferate."

These suggestions were investigated by M. B. Schmidt (1903 ${ }^{11}$ ) in a very prolonged microscopical investigation, in which he examined forty-five cases of abdominal carcinoma. The lungs of fifteen cases were macroscopically either free from tumours, or, at most, on the lung vessels there were found white riceshaped thickenings, which proved microscopically to be vessels obstructed with carcinoma cells. In a thorough examination of all these cases, macroscopically as well as microscopically, he found that the carcinoma cells were enclosed, as a rule, in thrombi, and rarely free in the blood stream. Almost always the cells were fixed in small arteries; they often formed nearly homogeneous masses, containing indistinct broken-up nuclei, which often did not stain at all; other cases showed clearly defined mitosis. In some cases the tumour cells were confined to the small arteries, and were not found elsewhere in the lung parenchyma. In other cases lymphatic vessels were also affected, and more rarely veins. Often he could follow the tumour entirely filling the vessel lumen in a long process extending from artery to capillary, and even to vein. At the same time he found regressive metamorphosis of carcinoma cells in fresh thrombi. Sometimes the connection of the tumour cells in the thrombi was very loose, and the latter contained many spaces which were incompletely filled by the tumour cells. Often necrotic cells were found in them; further, he saw leucocytes in and between the tumour cells. A very important part is played by older thrombi. Fresh tumour thrombi are organised by young fibroblasts, proliferated from the wall, and afterwards the growing cells are surrounded by connective tissue. The tumour cells in such a case are fewer in number, compared with fresh masses, but they maintain a healthy appearance.

All these figures, according to Schmidt's opinion, mean the destruction of the tumour cells during the organisation. Yet he is convinced that the tumour cells can grow in thrombi and be the starting-point for further metastases. $\mathrm{He}$ concludes as follows: "In the cases of earcinoma of abdominal organs the transportation of the tumour cells to small lung arteries occurs with considerable frequency. Only a small portion of these transported foci of growth form metastases, but the bulk are either killed by the organisation of their thrombotic covers, or encapsulated and made harmless, in spite of their preserving the power of proliferation; or they grow forward through the connectivetissue thrombi into the capillaries and veins, and may give rise to secondary tumours in the sphere of the systemic circulation; these can all occur without macroscopical change of the lung."

It is very interesting to consider that the carcinoma cell, according to the present opinion of the majority of investigators, is nothing but the host's own cell and not a foreign body such as a parasite. While it retains the power of proliferation to an abnormal degree, yet it is treated like a foreign body in the blood, from which it directly gets its nourishment, and at last for the most part loses its vitality. The same 
result was observed by Lubarsch (1905 ${ }^{12}$ ), Schiedat (1908 ${ }^{13}$ ), Kaufmann $\left(1911^{14}\right)$, and Kikuchi $\left(1914^{15}\right)$ in carcinoma cases, and Schmidt's theory is now generally accepted.

Now there arise further questions: Is this phenomenon restricted to carcinoma which forms secondary nodules in distant parts by spreading along the lymphatic vessels rather than the blood vessels? Does not this occur in other kinds of tumour especially sarcoma, which spreads by the blood vessels? Is this not found in the animal tumours which have recently been very much studied? Kikuchi is the only author who has touched the first question; up to the present no one has studied the second question. ${ }^{1}$

\section{INVESTIGATION OF POST-MORTEM MATERIAL.}

For my purpose I examined forty-eight cases of various kinds of malignant tumour and selected the following sixteen cases, including eleven cases of sarcoma (seven lymphosarcoma, and four other sarcomata), two cases of carcinoma, two cases of hypernephroma, and one case of chorion-epithelioma-like tumour of the liver. The microscopical description of these cases is as follows:

\section{Sarcomata.}

Case 1.-Male, æt. 60. Diagnosis.-Lymphosarcoma of the mediastinum, secondary nodules in bones of thorax, in liver, kidney, and glands, etc.

Mickoscopical Observatron.-Lung.-In the lumen of several veins near bronchial cartilages many sarcoma cells, either isolated from each other or massed together in a cell group, were found; sometimes they made a thrombus with fibrin, red and white blood corpuscles and blood platelets. In other parts these thrombotic masses were covered by a single layer of thin cells connected with the endothelium of the intima. The nuclei of the tumour cells in such a thrombus generally did not stain well. In one small vein a fairly big cell mass was fixed on the wall of the vessel, and the free surface was covered with a thrombotic mass, which again was partly surrounded by a thin layer of endothelium-like cells.

Liver.-In one vein there was a tumour-cell mass, penetrated by connectivetissue fibres derived from the wall ; the tumour cells here are mingled with a small quantity of fibrin. The capillaries contained many sarcoma cells, some of which showed distinct ficures of mitosis.

Kidney.-In a dilated vein a group of tumour cells loosely connected with each other was surrounded by a thin half ring of fresh thrombus. In another vein there was thrombus nearly obstructing the lumen; in the centre of this thrombus a number of degenerated sarcoma cells were to be seen. In a third vein there were two thrombi to be found in one seetion, one of which did not touch the wall, and contained sarcoma cells with very obscure outlines. The other thrombus was connected to the wall by a narrow pedicle of granular material, along this a mass of connective-tissue cells passed from the wall, surrounded the whole thrombus and sent some branches into its interior. Two or three groups of tumour cells occupy rather marginal parts of this thrombus, and are connected to each other by connective tissue; they look quite healthy.

In this case, therefore, the veins of the lung, liver, and kidney contained masses of tumour cells which were being encapsulated and destroyed.

${ }^{1}$ Since this was written a paper has appeared in this Journal (vol. xx. p. 1) by Dr, Takahashi which deals with this subject. -EDrror. 
Case 2.-Male, æt. 55. Diagnosis.-Lymphosarcoma of the neck, with extensive glandular involvement and necrosis, leading to ulceration, etc.

Mrcroscopical. - Lung. - Many arteries contain sarcoma cells, some of them are quite free in the lumina without any change in their appearance, but in other cases they are involved in thrombi, consisting of a granular mass, and taking very little hæmatoxylin stain. Many tumour cells, filling the lymphatics, are seen to be almost completely necrosed.

In this case the cells found in the lumen of the blood vessels are unchanged, the cells enclosed in thrombi and those in the lymphatics show necrosis.

Case 3.- Male, ret. 62. Diagnosis. - Lymphosarcoma of the neck, spreading by glands.

MicroscopicaL. - Lung.- - Many arteries are stopped by comparatively fresh thrombi with no tumour cells in them. Tumour cells are found in large numbers in the veins and capillaries; they are not in the normal state, some of them have no nuclei and show feebly stained protoplasm.

Here there is no sign of organisation, but the tumour: cells, lying free in the bluod, show definite signs of degeneration.

Case 4. - No record. Diagnosis.-Lymphosarcoma.

Microscopical. - Lung.- In one large vein there was a piece of tumour surrounded by red blood corpuscles and leucocytes; in a large vein near the lung hilum many small pieces of tumour were to be found, some of them quite free in the blood stream, but others in a thrombus. The lumen of another small vein was partly occupied by a thrombus adhering to the wall, consisting of fibrin, leucocytes, and connective tissue, with newly developed capillaries; its free surface was lined with an endothelial layer. In one part of this thrombus the loose fibrin net contained in its meshes a few tumour cells, which were poor in chromatin and irregular in shape.

Organisation and degeneration are both present in this case.

Case 5.-Male, at. 25. Diagnosis - Lymphosarcoma of the mediastinum, the abdominal cavity, and the neck.

Mrcroscopical. - Lung.-A few arteries contain in their lumina sarcoma cells, round which, as a rule, fresh thrombi are being deposited, and they are still free in the blood stream. In one place the thrombus is fixed to the wall by a thick pedicle of connective tissue that enters directly into the interior of the thrombus.

Gland in the thoracic cavity.-One vein is almost filled with tumour tissue, only a narrow space being left between this and the wall. At the place where the tumour is fixed on the wall the endothelium has proliferated from the wall, and covers the greater part of it. Besides, some connective-tissue fibres pass into the tumour and become its stroma.

In this case, therefore, organisation had proceeded to the formation of fully formed fibrous tissue in the vein of a tumour nodule situated in a lymphatic gland.

Case 6.-Male, æt. 50. Diagnosis.-Lymphosarcoma of the superior mediastinum, invasion of bronchial and lower tracheal glands, right lung and spinal canal, with softening of cord.

Microscopical. - Primary growth.-Many blood vessels contain tumour cells in various conditions. First, there are sarcoma cells, either in groups or isolated, that are not yet fixed to the wall ; they look quite normal. Such an embolus has a remarkable appearance. It is situated apart from the wall, but nevertheless several endothelial processes are proliferating from the intima towards it, and are passing to surround it from several directions. The tumour here is not quite a new embolus, the orderly arrangement of its cells shows that it has grown since it had become detached from the primary tumour. There is also to be found a tumour-cell mass fixed in a vein, and covered by a single layer of endothelium, directly derived from the wall. From this layer, as well as from the base, some connective-tissue fibres enter into the tumour. 
tissue and serve as its stroma. In other cases the sarcoma tissue has no such covering membrane, but stroma entering from the base can be seen. In one dilated vein the lumen is nearly filled with a thrombus attached to one part of the wall (Plate VIII. Fig. 4). The thrombus is comparatively fresh, consisting of fibrin and granular substance. The tumour cells occupy the basal part mainly, and are spreading along the surface of the thrombus, gradually becoming fewer as they advance farther from the base. These cells are arranged in a regular order, and their chromatin stains very distinctly, even mitosis can be found in them. At the middle of this long cell group, where it is thickest, a narrow cell process pointing towards the interior of the thrombus is to be seen. This figure leads me to suggest that the cell proliferation began at this point after the formation of the thrombus. At first it passed to the margin of the thrombus, and then spread along the surface. $\Lambda$ few tumour cells found in the thrombus stain very faintly, and are apparently degenerating. In another place a capillary springing from the wall is growing into a tumour mass in the vessel; at other points, the wall is penetrated by the tumour growing from inside.

In this case encapsulation and degeneration of tumour cells in fresh thrombus, together with the growth of them in the thrombus, are to be seen.

Case 7.-Male, æt. 36. Diagnosis.-Lymphosarcoma of the mediastinum ; invasion of right lung, pleura, liver, dura spinalis et cerebralis, muscles, etc.

Microscopical.-Liver-In a few veins there are many sarcoma cells, isolated or in groups, without any thrombus formation. The nuclei of some of these cells stain very weakly, or not at all; cells with nuclei in this condition were not to be found in the tumour tissue. In the capillaries, too, many tumour cells can be seen, generally in good condition, and even with mitosis.

The only sign of destruction of tumour cells in this case is the loss of staining seen in those situated in the liver veins.

Case 8.-Male, æet. 23. Diagnosis.-Small round-celled sarcoma of the left forearm; secondary deposit in pleura, lung, glands in root of lung, etc.

Microscopical. - Lung.- In an artery a fresh thrombus with a few tumour cells can be found; in another vessel (Plate VII. Fig. 3) the lumen is reduced to a space two-fifths of its diameter, and is situated excentrically. The remaining part is occupied by granular thrombus and fibrous tissue. This fibrous tissue is quite loose, and contains a few tumour cells in its meshes. These tumour cells, generally, are not healthy in appearance ; some stain pale, others are small, and a third group are ill-defined and indistinct, and at the same time there is some cellular débris. Many other arteries contain tumour cells more or less degenerated and mingled with fibrin threads and blood cells.

Organisation is fairly advanced in this case ; there is also cell degeneration.

Case 9.-Male, æt. 11 months. Diagnosis.-Sarcoma of the left suprarenal; secondary deposit in right suprarenal, both lungs, liver, and the glands along abdominal aorta.

Mioroscopical. - Liver. - In a fairly big vein there are a number of tumour cells held together by a thrombus consisting of a granular mass and fibrin threads; they look healthy.

Lumbar muscle.- Several veins contain groups of tumour cells, which, in many eases, are covered by a layer of endothelial cells. The tumour cells themselves look normal.

Fresh thrombi and proliferation of endothelium around tumour masses are seen in the veins in this case.

Case 10.-Male, xt. 40. Diagnosis.-Sarcoma of the liver; secondary deposit in peritoneum, pericardium, spleen, pleura, left kidney, suprarenals, pancreas, and glands along the aorta and at root of lung.

Microscopical. - Spteen. - In the parenchyma several tumour nodules can be seen; a great number of tumour cells fill the sinuses and give a peculiar 
appearance. One big artery contains two masses of tumour cells resting on the wall ; these have an endothelial covering over them, and, like other nodules, look quite normal. No thrombotic mass is to be seen.

Lung.-One artery lumen is almost obliterated by a thrombus containing a few well-preserved sarcoma cells : connective tissue is already making its way into the mass.

Fresh thrombi and proliferation of endothelium around tumour masses are to be seen in the vessels in this case.

Case 11. - Male, æt. 3 months. Diagnosis. - Sarcoma of the right suprarenal gland; secondary sarcoma of the left suprarenal and liver.

Microscopicat. - Lung.- In a section a tumour embolus is found in an artery. This is not covered by any thrombus, but the majority of the cells are degenerated, especially in their central part. $\Lambda$ few capillaries contain tumour cells in a healthy state.

Liver.-In the veins, capillaries, and arteries many tumour cells are mingled with blood cells and fibrin threads, but they are normal in appearance.

There is a considerable amount of degeneration in the tumour cells found in the veins, but there is very slight evidence of thrombus formation in this case.

\section{Carcinomata.}

Case 12.-Female, æt. 32. Diagnosis.-Recurrent carcinoma (primary in breast, removed previously) in liver and bones.

MrcRoscopical. - Lung.- Many arteries have carcinoma cells in various conditions; some of these are free in the lumen, and many of them are in groups in which the marginal cells are arranged in regular order; sometimes such a mass gives off a branch corresponding to the ramification of the artery. Mitosis as well as degeneration is very often found in the cancer cells, and a very few lymphocytes accompany them. In another artery a number of carcinoma cells is found in a thick cover of granular thrombus, which is firmly fixed to the wall; over the thrombus there is an endothelial layer. A small number of spindle-shaped connective-tissue cells are growing through the thrombus and the tumour mass. In one fairly large artery a small piece of tumour is surrounded by two processes of endothelium, like the breakwater of a harbour, but they are separated from the tumour by a narrow free space filled with blood cells. Some other arteries are filled with dense vascular conneetive tissue, in which a few tumour-cell groups are embedded. The spaces which these cell groups occupy are lined with endothelial cells. The tumour cells themselves are of irregular shapes, some are small, but others rather large and swollen, often the protoplasm is changed into granular débris, and contains no nucleus. In short, in the vessels are organised thrombi containing disintegrating cells in endothelial sacs. In many arteries the process of organisation is further advanced and shows connective tissue, already fibrous, very poor in nuclei; tumour cells and débris have disappeared; the section shows also the lumina of the capillaries newly developed in the thrombus; fresh tumour emboli are frequently to be found. In another section an artery lumen is narrowed by a few connective-tissue nodules on the wall; the shapes of these vary, one is quite flat, but another very projecting, and looks like a polypus. In no place could any proliferating tumour breaking through the artery wall be seen. No tumour cells remain in the veins and capillaries, but the lymphatics are still widely affected.

In this case organisation is in many instances complete in the blood vessels, but absent from the lymphatics.

Case 13.-Male, at. 38. Diagnosis.-Carcinoma of the pancreas, with secondary deposits in the peritoneum, retroperitoneal tissue, left kidney, stomach, pericardium, and epicardium. 
Microscopical.-Primary growth.-A vein partly surrounded by tumour cells contains vascular connective tissue with lymphocytes. In one corner of this there are about ten carcinoma cells showing the same characters as those outside the vessel, only they are separated from each other by connective-tissue fibres.

Local lymph gland.-Free tumour masses are found in a few veins and capillaries, but very rarely in arteries, some of these are penetrated by leucocytes. In one vein a number of carcinoma cells, mixed with many lymphocytes, stand on the wall, covered by a fibrous thrombotic mass, and an outer endothelial layer. The tumour cells lie loosely in the meshes, and have a normal appearance. In another vein there is a crescentic thickening of the intima in one part, and in this there are two or three spaces lined with endothelium; in each of these two or three cells, in an advanced stage of degeneration, are concealed. Some of these cells still have small and irregularly shaped nuclei, but others have no nuclear structure; the whole cell is nothing but an amorphous granular mass, with many vacuoles. A few small veins are to be found totally occluded by vascular fibrous tissue, in which also degenerated tumour cells may be observed. There is no doubt that not only these cells but also the débris come from the carcinoma. Lymph vessels contain also many carcinoma cells unchanged in character.

Definite signs of degeneration and of organisation are found in this case.

\section{Hypernephromata.}

Case 14.-Male, æt. 48. Diagnosis.-Hypernephroma of the left kidney ; secondary deposit in both lungs, in glands of root of lung, and posterior mediastinum.

MicroscopicaL - Primary growth.-Many veins and capillaries contain tumour masses or cells of the same appearance as those outside the vessels. In a fairly big vein one finds a large piece of tumour covered by a thin layer of connective tissue, from which some fibres enter into the tumour, and divide it into several areas. Many poly- and mono-nuclear leucocytes can be seen between the tumour cells; the tumour cells give no definite signs of degeneration. At one end of this long tumour column there is a thrombus (Plate VII. Fig. 1) of the shape of half a circle, the diameter of which forms the base of the thrombus; this is attached to the surface of the tumour mass. Some tumour cells of normal appearance and leucocytes are found in this. From the base connective tissue enters into the thrombus, just as at the beginning of organisation.

Lung.-Many tumour cells can be seen in arteries, veins, and capillaries, forming groups penetrated by leucocytes. Some of these emboli are visibly degenerated in their central parts.

Organisation in this case has reached only an early stage of development.

Case 15.-Male, æt. 57. Diagnosis.-Hypernephroma of the left kidney ; secondary deposit in the pancreas, lungs, mediastinal glands, thyroid, and vertebræ.

Mrcroscopical. - Lung. - In one of the blood-containing cavities, in which this tumour is very rich, there is a new thrombus containing leucocytes, and in the centre a mass of tumour cells. These cells, especially in their central part, stain very weakly; lymphocytes are also abundant in the tumour tissue.

Here organisation is absent, and the signs of degeneration are not very clearly marked.

\section{Chorion-epithelioma-like Tumour of Liver.}

Case 16.-Male, æt. 39. Diagnosis.-Malignant growth of the liver; secondary deposit in the peritoneal and retroperitoneal glands. 
Mroroscoprcal.-This is a very peculiar kind of tumour, the details of which will be published in another paper by Dr. James Miller and myself.

Primary growth.-The tumour consists of two kinds of cells-

1. Syncytium, directly lining blood vessels and blood cavities; and

2. Large quadrate or polygonal cells, like Langhans' cells in chorionic villi of placenta.

Indeed, these two kinds of cells form actual villi projecting into the blood cavities. The metastases in the glands have only one kind of cell, i.e., the epithelial cell.

Lung.-Several small arteries contain some tumour emboli and thrombi of various ages; in these the tumour cells consist entirely of those of an epithelial character. The newest thrombi represent those tumour cells with a granular mass covering them, the thrombus is either still flowing free in the blood strean or obstructing the lumen. The tumour cells seem in this stage quite normal, but afterwards they shrink, become defieient in staining, or swollen, while the nuclei show karyorrhexis; the thrombotic mass at the same time is penetrated by connective tissue budding from the walls. Comparatively healthy and degenerated cells are found together, and even mitosis can be seen in a somewhat fibrous mass (Plate VII. Fig. 2). The cross-section of some arteries is divided into several lumina by connective tissue, though no remains of tumour growth can be detected. In another artery an organised thrombus projects into the lumen like a polyp, and contains capillaries in itself.

Complete organisation with disintegration of the tumour cells is to be observed in the blood vessels in this case. At the same time active division of the remaining tumour cells occurs.

\section{SUMmary AND DIscUSSTON.}

The blood-vessel contents of tumour origin above described can be conveniently divided into the following groups:

1. The first group includes the naked tumour-cell emboli. These have newly entered into the vessels and are still free in the blood stream. The character of these is variable. In one case they appear to be normal, and from the orderly arrangement and the presence of mitosis one may suggest that they could proliferate in the vessels. In other cases degeneration is distinctly visible either in the protoplasm or in the nuclei. This destruction of cells sometimes occurs in the centre of a cell mass, but not regularly, and in one case I saw almost all the cells in a state of necrosis. The most striking figures are those in Case 6 (lymphosarcoma), and in Case 12 (carcinoma), where the naked tumour emboli did not touch the wall; this fact I proved by serial sections. Nevertheless, several endothelial processes of varying thickness are proliferating towards them and endeavouring to involve or to reach them. From these observations I think that endothelium must have the power to proliferate towards any foreign body, though it is not in direct touch with it. Hence, if the tumour emboli had remained there for some time, though not in direct contact with the wall, those appearances could be well understood.

2. To this group belong those tumour emboli with comparatively fresh thrombotic covers. These are found either in the blood stream 
or already fixed to the vessel walls. The tumour cells are not always in the centre of them, but very often in an excentric site and sometimes in large numbers. Thrombus formation does not necessarily occur before the tumour mass settles on the wall. This is well shown in Case 1, where an embolus resting on the wall is eovered by thrombus only over its free surface. The simple encapsulation of a tumour cell group by a thrombus generally causes degeneration of the cells in the interior by depriving them of nourishing fluid, but some cells can remain intact and even proliferate further, especially those in the marginal part of the thrombus. Case 6 (Plate VIII. Fig. 4) gives a good example of this contrast, where the cells in the interior of a thrombus are all more or less degenerated, while those near the surface are growing, and after they have reached the surface are spreading along it.

3. The third group contains those thrombi in which the process of organisation is visible. From the wall, on which they stand, proliferating connective tissue enters into them and between the tumour cells. In most cases the proliferating endothelium is passing to cover the thrombus. Tumour-cell degeneration proceeds further, but even in this stage we may see the figures of mitosis (Plate VII. Fig. 2).

4. The process of organisation advances further. The contents of the vessels consist of fibrous tissue with capillaries newly developed, and tumour cells. Around these tumour cells, which are mostly divided into small groups or separated from each other, there are endothelial membranes lining the spaces in the connective tissue in which the tumour cells are situated; on account of their shrinkage the tumour cells do not fill up these spaces. The cells themselves generally show marked degeneration, sometimes with very small nuclei, but at others even these disappear, and we see only amorphous and vacuolated masses as the débris of them. At the same time they can still remain in a normal state even when advanced organisation has taken place; though I could not find any mitosis or other sign of proliferation in this stage, I think Schmidt's statement, that after a long interval such cells can still afford a source for a late recurrence, is correct.

5 . In this group I include those fibrous contents of vessels in which no trace of tumour cells is now to be seen (Cases 12 and 16). The organisation and tumour cell destruction are complete, and the lumina are for the most part reopened by new capillaries, in which sometimes again new tumour emboli are found. The organised masses are of various shapes, sometimes like polyps, sometimes nodular, or, again, merely circumscribed thickenings of the wall. The capillaries are found generally in numbers and in an excentric site, so that it is not difficult to distinguish these changes in blood vessels from those of arterio-sclerosis to a high degree.

6. Finally, I may add another group which, in my opinion, has no relation to disintegration of tumour cells. The tumour cell mass is here covered by a thin layer of endothelium continuous with the 
intima. Though a small number of leucocytes may be found between the tumour cells, the latter appeared to be normal: no sign of degeneration can be seen. Some connective-tissue fibres from the wall, as well as cells from the covering endothelium, are thrust into the mass: these serve as stroma (Plate VIII. Fig. 5). Schmidt gives a figure of this kind in his monograph and regards the covering as a carcinoma cell layer newly developed at the place, and he simply says that the growing over of endothelium in these cases is not to be thought of. Kikuchi finds the same figure in his case of melanosarcoma, but he thinlis it is a connective-tissue membrane, and the whole figure shows merely a stage of organisation. New formation of capillaries, too, he explains as an act of organisation. I could not find similar appearances in my cases of human carcinorna, but saw them in many cases of sarcoma and of mouse carcinoma, to which I will refer later. In my opinion they are of endothelial nature, as Kikuchi held, because it is improbable that tumour cells become so thin, and, moreover, very often there is direct transition from these cells to those of the intima. At the same time $I$ cannot agree with him in considering it to be a degenerating form: the cells are healthy and sometimes show mitosis; they have an orderly arrangemeut in the margins; and, above all, they actually penetrate the vessel wall. I regard them as the first stage of metastases formation; at the same time, I consider that penetration of the wall by tumour cells from inside can sometimes occur without such an endothelial cover.

The descriptions given under Groups II. to V. deal with the same process of the organisation of a thrombus containing carcinoma cells, that Schmidt noticed for the first time. He tells us that this process occurs in every kind of carcinoma, in comparatively benignant scirrhus, as well as in malignant carcinoma medullare. If we look at lymphosarcoma as differing from the usual sarcomata, in that the former propagates itself mainly through the lymphatics, while the latter prefer the blood vessels, my material includes four or five kinds of malignant tumour, in three or four kinds of which the process was already fairly advanced; and though in the last variety (hypernephroma) I could see only the beginning stage of organisation, I believe I can extend what Schmidt asserted of carcinoma only, so that it applies to malignant tumours generally. The question, what kind of tumour suffers most from this means of destruction? could be decided only by minute examination of a sufficient number of cases. But it may be suggested that in those kinds which form metastases by the lymph paths this destruction by the blood will occur more frequently than in those that spread by the blood vessels.

Although destruction is the general fate of those cells once caught by a thrombus, some preserve their vitality for a long time, as can be seen in Case 16, where, in a fairly advanced organised thrombus, a mitosis shows that the cells have still the ability to proliferate. 


\section{Action of Blood Plasma on Tumour Cells.}

The discovery of Schmidt was so much welcomed by other authors that, whenever they wanted to say something about the deleterious action of the blood upon tumour cells, they always introduced his theory, as if the activity of the thrombus were the only activity involved; the direct action of the plasma has thus been almost neglected. Schmidt's results do not justify such an interpretation. Teacher suggests this effect in saying that, possibly, hæmorrhage exerts a deleterious influence on the tumour (chorion-epithelioma) cells. Kikuchi finds that, in every case, as soon as a tumour invading the blood vessel reaches the lumen from the outside, it is more or less changed in its character. From this observation he concludes that he has proved the harmful effect of blood plasma upon tumours. But in other places he insists that in those cell masses found freely in vessel lumina, the central parts are, in nearly all cases, in a state of necrosis, while the marginal parts show proliferation. This does not coincide with his first observation, nor with his conclusion from it, because if the plasma is harmful to tumour cells, the marginal parts must be attacked first, as his early observation shows, and the central cells must remain in a better condition. We cannot, therefore, accept his argument without some hesitation.

Levin and Sittenfield $\left(1911^{16}\right)$, from the result of their animal experiments, deny this capacity of the plasma. They inoculated rat sarcoma suspension subcutaneously, together with rat serum, into rats, and saw growth of the tumour in 75 per cent. of the animals. They also put a small piece of the tumour in the bone-marrow of the animals, where they believe the piece of tumour must be in constant contact with circulating blood, and got 80 per cent. of positive results. But both these experiments seem to me inadequate. In the first case, the quantity of serum must be insufficient to neutralise all the tumour cells, so the conditions of the experiment are not to be compared with the natural process in blood vessels, where fresh plasma is constantly streaming over the introduced tumour cells. In the second experiment, too, the action of the plasma must be limited, because here a piece of tumour was used and not a suspension of cells, so the contact surface of it with blood fluid is very limited compared with that in the natural metastases formation. Though, in any case, some cells may be killed by plasma, others grow sufficiently rapidly to fill their places, and, further, to form a tumour nodule.

To decide this question I have carefully counted tumour cells found free in blood vessels, and calculated what percentage of them is disintegrating, and have compared this percentage with that of tumour cells in lymph vessels and in tissue spaces. As blood and lymph vessels $I$ have selected only those where the tumour does not as yet fill up their lumina, in order to avoid counting the cells dis- 
integrating by pressure from the wall. For similar reasons I have chosen those cells in the marginal fresh parts. I was able on this account to use only eleven cases for this purpose, and those mainly sarcomata. 1)egeneration and non-degeneration are a matter of degree, and not always easy to distinguish, so I endeavoured to adopt carefully the same standard, especially in the same case.

Tabie 1.-Percentage of Disintegrating Cells.

\begin{tabular}{|c|c|c|c|c|c|}
\hline & CAsl: & & In Tissue. & $\stackrel{\text { In }}{\text { Lymphatics. }}$ & $\operatorname{In}_{\text {Blood Vessels. }}$ \\
\hline 1. Lympho- & -sarcoma & $\cdot \cdot \cdot \cdot$ & $17 \cdot 0$ & $19 \cdot 7$ & $27 \cdot 4$ \\
\hline 2. $\quad$, & ," & . . . . & $11 \cdot 1$ & $\ldots$ & $25 \cdot 9$ \\
\hline 3. & , & $\cdot \cdot \cdot \cdot$ & $6 \cdot 6$ & $\ldots$ & $16 \cdot 1$ \\
\hline$"$ & ," & . . . . & $20 \cdot 4$ & $\ldots$ & $25 \cdot 2$ \\
\hline 6. , , & ", & . . . . & $17 \cdot 1$ & $20 \%$ & $20 \breve{5}$ \\
\hline ร. & $"$ & . . . . & $13 \cdot 7$ & $18 \cdot 4$ & $35 \cdot 6$ \\
\hline 8. Sarcoma & . . . & . . . . & $16 \cdot 0$ & $\ldots$ & $36 \cdot 9$ \\
\hline ," & . & $. \quad . \quad \cdot$ & $17 \cdot 2$ & $17 \cdot 9$ & $16 \cdot 7$ \\
\hline $10 . \quad$, & $\cdot \cdot$ & $\cdot \cdot$ & $20 \cdot 6$ & 20.9 & $25 \cdot 4$ \\
\hline ," & . & $\cdot \cdot$ & $25 \cdot 3$ & $19 \cdot 2$ & $22 \cdot 0$ \\
\hline 12. Carcinorn & ma. & . . . & $11 \cdot 6$ & $16 \cdot 5$ & 30.5 \\
\hline
\end{tabular}

From Table I. it is clear that the cells in blood vessels are the most degenerated, and, though there are some exceptions (Cases 9 and 11), their differences are so insignificant that I may neglect them. Besides, I found occasionally in blood vessels, tumour masses consisting of degenerated cells only. Such figures, together with the percentages in Table I., can be explained only by the deleterious action of blood plasma upon tumour cells.

The question whether lymph plasma has the same action or not I cannot decide, the difference in the percentages of disintegrating cells in tissue and lymphatics being too small.

\section{Conclusions relating to Tumours of Man.}

I. The destruction of tumour cells in blood vessels by means of thrombus organisation is not restricted to carcinoma, but is common to all malignant tumours.

II. The destruction of cells occurs also in blood vessels by direct action of the plasma. 
III. The thin cell layers that directly cover tumour masses are of endothelial nature, and do not consist of tumour cells. When the encapsulation takes place the tumour cells proliferate, and the mass is not disintegrated by organisation and degeneration. In such cases the covering layer of endothelial cells may possibly act as a protection of the tumour cells from the cytolytic action of the plasma.

\section{ANIMAL EXPERIMENTS.}

Malignant tumours of animals are, in several respects, not the same as those of the human subject. Goldmann (1911 ${ }^{7}$ ) found that the mouse carcinoma forms metastases by the blood circulation, but not by the lymph, direct invasion of blood vessels being a regular occurrence. Hansemann (1912-13 ${ }^{18}$ ) even doubts the malignity of the mouse carcinoma, for the following reasons:-(1) It reaches a considerable size compared with the whole animal body; (2) cachexia does not occur; (3) the limitation is sharp; (4) metastases occur very seldom. His opinion has been attacked by several authors, Apolant (1912 19), Murray $\left(1908^{20}\right)$, etc. In view of the differences of opinion as to the identity of human and animal carcinoma, it is necessary to investigate further this subject of destruction of tumour cells in the blood in cases of animal tumours.

\section{The Method of Investigation.}

The research work was done chiefly on Jensen's rat sarcoma, and in a few cases the mouse carcinoma was also used; both of these I obtained from the Imperial Cancer Research Institute in London, by the courtesy of Dr. Murray, to whom I now express my hearty thanks.

Tumour suspension was in physiological saline solution; the tumour was cut with scissors into fine pieces, so that they passed through the usual needle for subcutaneous injection, and, withont filtering, it was injected into a femoral vein in doses on the average of 0.5 c.c. in rats, and 0.2 c.c. in mice. Of the fifty-two rats used, twenty-nine had a subcutaneous, and subsequently an intravenous inoculation; the remaining twenty-three had an intravenous injection only. These rats were killed at different intervals, from immediately after the injection up to the fiftieth day, and the whole lung tissue was examined in serial paraffin sections.

Seven mice were examined; all had intravenous inoculation only. They were killed at intervals up to a period of twenty-nine days.

\section{Summarised Microscopical Description and Discussion.}

The process of destruction of tumour cells in the blood vessels is just the same as in the case of tumour in the human subject. The 
encapsulation of tumour cells of the rat sarcoma in a thrombotic mass has commenced in the rat killed ten minutes after the injection of the suspension. These thrombi are either tightly wedged in artery lumina, or are touching the wall with one side, very often at the division of the vessels. Those parts in which the thrombi or emboli are wedged are often found dilated, and the elastic membrane becomes very thin. The cause of this vessel dilatation, which has been found in human cases also, seems to be speedy streaming of the blood acting on the elastic wall, and is not a special characteristic of thrombotic tumour masses, but is common to every embolus. I saw the same phenomenon in a simple tumour embolus with no thrombotic cover in an animal killed just after the injection. The pressure of the blood stream drives embolic masses into the vessels, the calibre of which is narrower than the diameter of the emboli, as far as the elasticity of the walls will admit. Mononuclear leucocytes accompany thrombi in the early stages, but later their number seems to diminish. Then connective tissue proliferates from the wall and penetrates and covers the thrombi; the formation of new capillaries also follows. The tumour cells inside gradually degenerate, they stain more faintly, shrink, or fall into karyorrhexis.

In another case proliferation of the tumour cells may take place. Some emboli remain naked, and in this state they begin to grow after a short time. In other cases, even the cells in the thrombi, especially in their marginal parts, begin to grow, so we very often see the grouping of fresh cells along the margin of a thrombus. The growth of tumour oceurs both along the vessel lumen and outward through the wall. The rapidity of tumour development differs considerably in different cases. Sometimes we see microscopical growth taking place on the first day, and a macroscopical tumour on the sixth day, but in other cases a tumour of similar size is found on the fiftieth day, and in a third case we may find healthy looking and even growing cells in a thrombus forty-eight days old, without finding any other tumour nodules. These facts prove that the tumour cells can remain a long time in a thrombus without suffering any alteration, and can still grow.

In the case of mouse carcinoma, though the material was scanty, I. found almost the same figures, such as thrombus building, wandering lencocytes, connective-tissue proliferation, and tumour-cell degeneration. In one case, killed twenty-nine days after the injection of the suspension, the tumours were so far developed that no trace of the primary thrombus could be found. But what interested me very much was the number of thrombi in the veins, apparently arising from the nodules existing in the lung, as their fresh appearance indicated. This was the only case in my animal experiments in which I found natural thrombi. Their appearances are the same as those of thrombi due to artificial injection.

In cases of mouse carcinoma I again observed the appearances which I have described in cases of human sarcoma, that is, the tumour 
cell group on a vessel wall, having a single endothelial layer directly covering it. The carcinoma cells of such fixed emboli appear to be in a healthy condition in every respect, and in the cases where connectivetissue bundles thrust into and divide them up, they have the common appearance of alveolar carcinoma and are not to be considered as degenerating or organising at all.

Indeed, the period of my observation was not long enough to see the complete organisation of thrombi, but as they all show the appearances seen in an ordinary thrombus, further observation is almost unnecessary. So I believe I am not mistaken if I conclude that the same rule as to the destruction of malignant tumour cells in human blood vessels holds also in animal tumours.

\section{Statistical Observation of MY Anjmal Experiments.}

The results of my experiments are given in the following three tables. At first I thought there might be some difference in the microscopical appearances of the emboli and thrombi in lung arteries between two classes of tumour animals, one of which had already a subcutaneous tumour, while the other had none, at the time when the individuals were treated with intravenous injection. But as this suggestion was not substantiated I have described them in my summary. Table II. includes those animals subcutaneously inoculated, with positive or negative result, and Table III. those which had only an intravenous inoculation. Table IV. includes the experiments on mice.

\section{TABLE II.}

\begin{tabular}{|c|c|c|c|c|c|c|c|c|c|c|}
\hline No. & 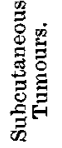 & \multicolumn{2}{|c|}{$\begin{array}{c}\text { Duration of } \\
\text { Experiment. } \\
\text { Killed or Died. }\end{array}$} & $\begin{array}{l}\text { Lung } \\
\text { Tumiour. }\end{array}$ & No. & 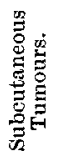 & \multicolumn{3}{|c|}{$\begin{array}{l}\text { Duration of } \\
\text { Experiment. } \\
\text { Killed. }\end{array}$} & $\begin{array}{l}\text { Lung } \\
\text { Tumour. }\end{array}$ \\
\hline 1 & + & 10 minute & killed & & 16 & + & & days, & killed & + \\
\hline 2 & + & 1 day & , & & 17 & + & & ," & died & - \\
\hline 3 & + & 1, & ", & & 18 & + & & $"$ & $"$ & - \\
\hline 4 & + & & ", & & 19 & t & 17 & & $"$ & - \\
\hline 5 & + & 3 days & $"$ & & 20 & +- & 23 & & ,ill', & - \\
\hline 6 & + & 3, & ," & & 21 & +- & & & killed & - \\
\hline 7 & + & $3 "$ & ", & & 22 & + & & & ," & - \\
\hline 8 & + & $6 "$ & ," & + & 23 & - & & d of 1 & $\mathrm{~g} \mathrm{em}-$ & \\
\hline 9 & + & 6, & " & $\overline{-}$ & 0 & & & oli & rilled & \\
\hline 10 & + & $\begin{array}{r}6 \\
13\end{array}$ & ", & t+ & $\begin{array}{l}24 \\
25\end{array}$ & $=$ & & $\begin{array}{l}\text { day } \\
\text { days }\end{array}$ & killed & - \\
\hline 12 & + & $13 "$, & ", & + & 26 & - & 35 & $y$ & died & + \\
\hline 13 & + & 13, & ", & + & 27 & - & 38 & ," & killed & - \\
\hline 14 & + & $21 "$ & ", & -- & 28 & - & 38 & ," & ," & - \\
\hline 15 & + & 21, & ," & - & 29 & - & 38 & , & , & + \\
\hline
\end{tabular}


TABLE III,

\begin{tabular}{|c|c|c|c|c|c|c|c|}
\hline No. & $\begin{array}{l}\text { Durat } \\
\text { Exper } \\
\text { Killed }\end{array}$ & $\begin{array}{l}\text { of } \\
\text { ont: } \\
\text { oied. }\end{array}$ & $\begin{array}{l}\text { Isung } \\
\text { Tumour. }\end{array}$ & No. & \multicolumn{2}{|c|}{$\begin{array}{l}\text { Duration of } \\
\text { Experiment. } \\
\text { Killed or Died. }\end{array}$} & $\begin{array}{l}\text { Lung: } \\
\text { Tumour. }\end{array}$ \\
\hline $\begin{array}{l}30 \\
31 \\
32 \\
39 \\
34 \\
35 \\
36 \\
37 \\
93 \\
39 \\
40 \\
41\end{array}$ & $\begin{array}{l}7 \text { days, } \\
7 \%,, \\
17,, \\
19,, \\
23,, \\
23,, \\
23,, \\
27,, \\
28,, \\
34, \\
34, \\
33,\end{array}$ & $\begin{array}{c}\text { killed } \\
\text { died } \\
\text { killed } \\
\text {,, } \\
\text { died } \\
\text {,, } \\
\text { killod }\end{array}$ & $\begin{array}{l}+ \\
+ \\
+ \\
+ \\
+ \\
+ \\
+ \\
+ \\
+ \\
+ \\
+ \\
\cdots\end{array}$ & $\begin{array}{l}42 \\
43 \\
44 \\
45 \\
46 \\
47 \\
48 \\
49 \\
50 \\
51 \\
52\end{array}$ & $\begin{array}{l}33 \text { days, } \\
45 \text {,, } \\
39 \text {, } \\
48 \text {,' } \\
49 \text {,, } \\
50 \text { ", } \\
45 \text { ", } \\
45 \text { ", } \\
30 \text {, } \\
30 \text { ', } \\
30 \text { ", }\end{array}$ & $\begin{array}{c}\text { killed } \\
\text { died } \\
,, \\
\text { killed } \\
\text {," } \\
\text {, } \\
\text { ", } \\
\text { ", } \\
\text {," }\end{array}$ & $\begin{array}{l}+ \\
+ \\
+ \\
+ \\
- \\
+1 \\
- \\
- \\
+ \\
+ \\
+\end{array}$ \\
\hline
\end{tabular}

TABLE IV.

\begin{tabular}{|c|c|c|c|}
\hline No. & \multicolumn{2}{|c|}{$\begin{array}{l}\text { Duration of } \\
\text { Experiment. } \\
\text { Killed or Died. }\end{array}$} & $\begin{array}{l}\text { lung } \\
\text { Tumotir. }\end{array}$ \\
\hline 1 & 3 hours, & died & \\
\hline 2 & 1 linur', & killed & \\
\hline 3 & if honds, & $"$ & $+t$ \\
\hline 4 & 14 &, & 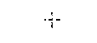 \\
\hline 5 & 29 & , & - \\
\hline 6 & 29 & , & $t$ \\
\hline 7 & 20 & ", & $\cdots$ \\
\hline
\end{tabular}

Sticker reported that all the living tumour cells introduced into blood vessels die away, giving the organism immunity. Levin and Sittenfield, too, have told us that in spontaneous animal tumour there are very few metastases, and to cause them by injecting tumour cells directly into blood vessels is also difficult. They (Levin and Sittenfield) injected rat sarcoma suspension into the jugular veins of thirty-six rats and into the carotid arteries of six rats, and saw no tumour formation at all, although the same material gave 90 per cent. positive results in the case of subcutaneous inoculation. Small pieces of tumour inoculated into bone-marrow of ten rats (in which tissue they believe that the cells come in contact with circulating blood) gave also quite a negative result in originating metastases in distant organs, though local tumour developed in 80 per cent. Of fifty-four rats treated with rat carcinoma (sixteen intravenous, seven intra-arterial, seven into bone-marrow, and twentyfour into the cavities of knee-joint, in which the authors expected the tumour to be absorbed by the lymphatics), one heart and ten lung tumours were obtained: twenty mice intravenously injected with mouse sarcoma were all negative. Of twenty-seven rats treated with the same mouse sarcoma (twelve intravenously and fifteen into the knee-joint), three developed liver tumour, and one a proliferation of tumour cells in a peri-glandular artery in the inguinal region, 
The results of Levin and Sittenfield differ very considerably from mine. In my experiment (Table III.), only four out of twenty-three rats intravenously treated with Jensen's tumour ended negatively $(17.4$ per cent.); this percentage is rather smaller than that with the subcutaneous inoculation (Table II.), where seven out of twentynine (24.2 per cent.) were negative. Three out of five mice treated intravenously were positive. Even in twenty rats which were treated once with subcutaneous inoculation with positive or negative result, and then intravenously injected and survived at least six days, I got seven positive cases. The great difference between the result of the two authors named and my own must be caused by different methods of preparing the suspension. They used Haaland's mincing machine, and, moreover, filtered the fluid with a rough gauze; their suspension, therefore, must have contained only very fine particles of tumour, perhaps consisting of only a few cells. According to my microscopical study those tumour cells which are destroyed in the thrombus are mostly isolated cells, so that their cells must have been killed, or at least enclosed in thrombi for a long time, though Levin and Sittenfield would deny the existence of such a deleterious action of blood. On the other hand, they killed the animals too early after the injection (four to twenty-eight days); if they had waited somewhat longer they might have had more positive results, for tumours in blood vessels sometimes develop very slowly. From my results I hold that it is not difficult to cause tumours by inoculating foci directly into vessels.

Next, the two authors insist that there must exist some specific affinity between tumour cells and cells of certain organs, for the reason that, irrespective of the mode of inoculation, they got lung tumours only when rat carcinoma was injected into rats, and liver tumours only when mouse carcinoma was injected into rats. These results also do not coincide with what I have observed. I saw only lung tumours, except in two cases: in one of them (No. 40) a large nodule was seen in the right inguinal region, at the site of injection, so I do not doubt this was implanted at the time of the injection. In another case (No. 51) a small nodule was found in the epicardium, and in this case lung tumours had broken into the thoracic cavity, a result which was due to implantation and not to spreading by the blood. Mouse carcinoma was also found exclusively in the lung. I cannot, therefore, accept their theory of specifie affinity, and should take their three cases of liver infection as being merely an accident.

Anton Sticker $\left(1909^{8}\right)$ suggests that the animal body carrying a tumour must consist of two zones-a tumour zone and an immune zone. The tumour zone represents the place where the tumour exists and toxic action helps the proliferation of the tumour. The immune zone includes the remaining part of the body, in which there is an opposite action. So long as this state continues the tumour can grow in its sphere and can enlarge this sphere, but the second tumour 
development in distant organs is impossible, either by the usual lymph or blood channels, or by the way of implantation. By the extirpation of the tumour the antibodies in the immune zone disappear very quickly, so that it becomes again possible to transplant a tumour in this zone. Against Hertwig and Poll (1907 ${ }^{21}$ ), who always got positive results in the second implantation, Sticker said that their material must have been less malignant, and as they implanted on the same side perhaps it may have corresponded to the zone he named the tumour zone.

This theory seems quite absurd, because if this were true there would exist no distant metastases of tumour. Besides, in my experiment five rats out of fifteen $(33.3$ per cent.) were, after successful subcutaneous inoculation, again successfully inoculated intravenously (Table II., from Nos. 8 to 22). This percentage is too large to be neglected as a simple exception, and the excuses with which Sticker pushed aside the opposite result of Hertwig and Poll cannot apply in my cases. Jensen's tumour is fairly malignant, and as the second implantation was always in lung, while the first, being in flank, it would be impossible to take these two parts together as a single "tumour zone."

Uhlenhuth, Hïndel, and Steffenhagen $\left(1911^{22}\right.$ ) argue that if in an animal subcutaneous, intraperitoneal, or intraparenchymatous inoculation does not succeed, or if a tumour spontaneously regresses, it becomes further immune, etc. This result differs from that of Kraus, Ranzi, and Ehrlich (1910 ${ }^{23}$ ), who proved that peritoneal implantation can be successful on an animal on which the inoculation into the subcutis or abdominal organs has ended negatively. There are five cases in my Table II. (Nos. 20 to 24), in which subcutaneous implantation failed: thirty-four to thirty-eight days after that intravenous injection was done, and the animals were examined after a period of more than 15 days. To this I add two cases (Nos. 20 and 21) in which developed subcutaneous tumours again disappeared. Of these seven cases, two developed lung nodules. This ratio (2:7) is about the same as that $I$ have just given in my argument against Sticker $(5: 15)$, and leads me to the conclusions which I give below. This fact must be kept in mind by those who study tumour immunity.

\section{Conclusions from the ANTMAL Experiments.}

1. The destruction of tumour cells in blood vessels by means of thrombus organisation is not restricted to human neoplasms, but occurs equally in animal tumours.

2. Nevertheless, all tumour cells introduced into blood vessels do not necessarily disintegrate, as several authors believe, but if the technique is suitable, the lung will be attacked in a very considerable number of cases. 
3. The theory of the specific affinity between tumour cells and cells of certain organs must be accepted with great reserve.

4. The "two zones" theory of Sticker is quite groundless.

5. An inoculation confers on the animal a certain degree of immunity to the subsequent implantations, quite irrespective of the result of the first implantation. (Compare Table II. with III.)

I wish here to express my indebtedness to Professor J. Lorrain Smith for his kindness in placing material at my disposal and for his guidance in the preparation of this paper.

\section{REEERENCES.}

1. ОRтн . . . . . . . "Ueber Heilvorgänge an Epitheliomen, nebst allgemeinen Bemerkungen ueber Epitheliome," Ztschr. f. Krebsforschung, 1904, Bd. i. S. 399.

2. Handiey . . . . . " "Cancer of the Breast and its Operative Treatment," London, 1906.

3. Petersen and Colmens . Beitr. \%. klin. Chir., Tübingen, 1902, Bd. xxxii. ; 1902, Bd. xxxiv. S. 682 ; and 1904, Bd. xliii. S. 1.

4. Shangre, E. . . . . . "Ueber die spontane Heilbarkeit des Carcinoms," Verhandl. d. deutsch. Gesellsch. $f$. Chir., Berlin, 1894, Bd. i. S. 171.

5. Rieser. . . . . . . "Ueber d. malignen Chorionepitheliom," Arb. aus der path. Inst. z. Leipzig, 1903, Heft 1, SS. 55, 56, 65 .

6. Michel . . . . . . "Chorionepithelioma nach Blasenmole mit grossen Metastase der Scheide u. Lungenmetastase geheilt," Centralbl. f. Geburtsh. u. Gynaec., 1909, Bd. xxxiii. S. 1057.

7. Teacher . . . . " On the Development and Natural Healing of Secondary Tumours of Chorionepithelioma malignum," Journ. Path. and Bacteriol., Cambridge, 1907-1908, vol. xii. p. 487.

8. Anton Sticker . . . " "Die Immunität und die spontane Heilung der Krebskrankheit nach den Ergebnissen der modernen experimentellen Forschung," Ztschr. f. Krebsforschung, 1908, Bd. vii. S. 55.

9. Golmmann . . . . "Anatomische Untersuch. ueber die Verbreitungsweise bösartiger Geschwuelste," Beitr. z. llin. Chir., Tuibingen, 1897, Bd. xviii. S. 595.

10. Lomer. . . . . . "Zur Frage der Heilbarkeit des Carcinoms," Ztschr.f. Geburtsh. u. Gynaec., 1883, Bd. ix. S. 277.

11. M. B. Schmot . . . . "Die Verbreitungswege der Karcinome u. die Beziebung generalisierter Sarcome zu den leukämischen Neubildungen," Jena, 1903.

12. Lubarsch. , . . . . "Lehrbuch d. allg. Pathologie," Wiesbaden, 1905. 
13. SCHIEDAT . . . . . "Ueber den Untergang malignen Geschwuelstmetastasen in der Lunge, Leber und Lymphdruesen," "Inaug-Diss.," Koenigsberg, 1908.

14. Kaufmann . . . . . "Specielle path. Anat.," 1911.

15. KikuciI . . . . . . "Verhalten der boesartigen Geschwuelste gegenueber den Blutgefaesse," Mitth. der med. Gesellsch. z. Tokyy, 1914, Bd. xxviii. Heft 1.

16. Levin and Sittenfield . "On the Mechanism of the Formation of Metastases in Malignant Tumours," Journ. Exper. Med., Baltimore, 1911, vol. xiv. p. 148.

17. Goldmann . . . . "Studien zur Biologie der boesartigen Geschwuelste," Tuibingen, 1911.

18. V. Hansemann . . . . Berl.klin. Wehnschr., 1913, S. $81 ; 1912$, Bd. xlix. S. 8.

19. Apor $\mathrm{N}^{\prime}$ ' . . . . . "Ueber die Natur. der Maeuse-geschwuelste," Berl. klin. Wehnschr., 1912, S. 495.

20. Murray . . . . . . "Third Scientific Report on the Investigation of the Imperial Cancer Research Fund," London, 1908.

21. Hentwig and Poll. . . Abhandl. der Kögl. preussischen Acad. $a$. Wiesbaden, 1907.

22. UHLENHUTH, HÄNDEL, AND "Experimentelle Untersuchungen ueber Stefrinhagen. "Rattensarcom," Arb. aus dem Kaiserl. Gesundheit., 1911, Bd. xxxvi. Heft 4, S. 465.

23. KRaUS, Ranzi, and EHrLich "Studien ueber Immunität bei malignen Geschwuelsten," Ztschr. f. Immunitätforschung, 1910, Bd. vi. S. 665 .

\section{DESCRIPTION OF PLATES VII.-IX.}

Figs, 1-5.-Post-Mortem Material.

Figs. 6-9.-From Animat Expriments.

The sections were all stained with hematoxylin and cosin.

\section{Plate VII.}

FIG. 1 (Case 14).-Hypernephroma: Section of a vein in the primary growth. $(x 110$.

(a) Thrombus consisting of fibrin, leucocytes, and blood platelets : in the centre are numerous tumour cells.

(b) Alongside the thrombus is a column of tumour cells growing in the lumen of the vein.

(c) Vessel walls.

Frs. 2 (Case 16).--Chorionepithelioma-like tumour: Section of a pulmonary artery. $(\times 300$.

$(a, b)$ Tumour cells in a fibro-fibrinous thrombus; some are small, others swollen, but one cell in the group $(\alpha)$ shows mitosis,

(c) Blood cells in the Iumen.

FIs. 3 (Casc 8).- Sarcoma of the left forearm: Section of a lung artery. $(\times 400$.

(a) Tumour cells in the meshes of fibrous tissue.

(b) Fibrinous remains of the original thrombus.

(c) Lumen containing red blood cells, 


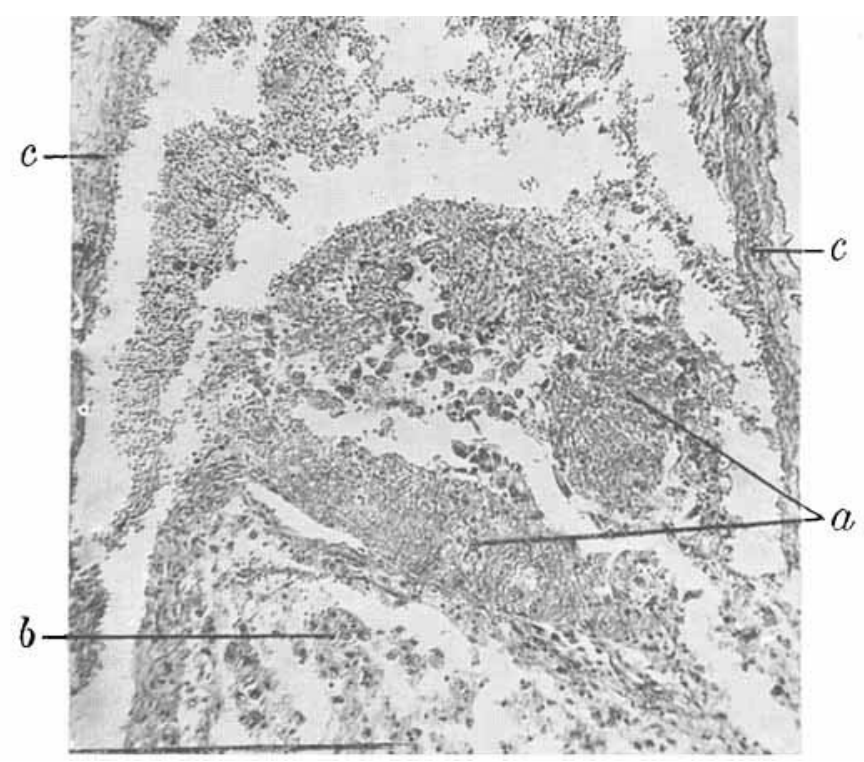

Fig. 1.

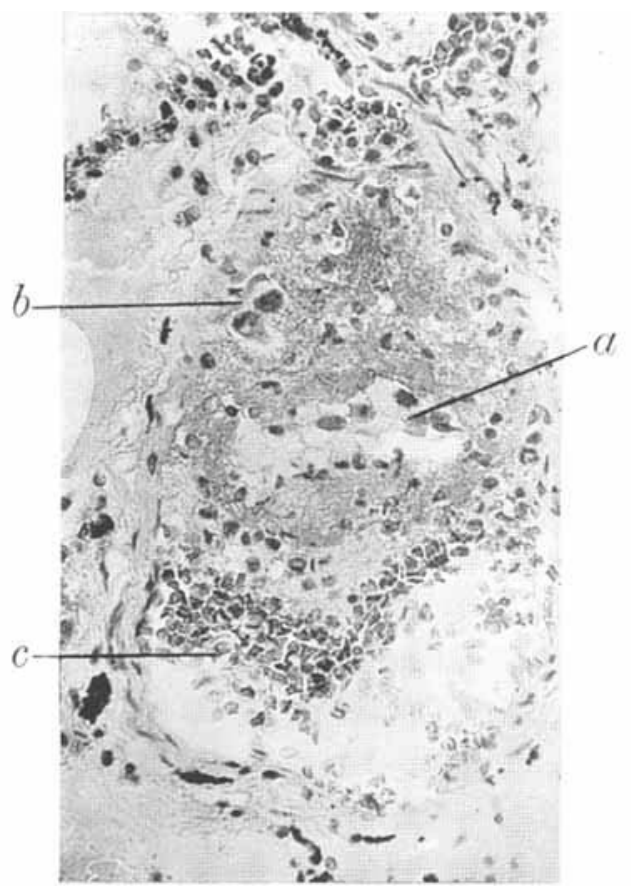

Fit. 2.

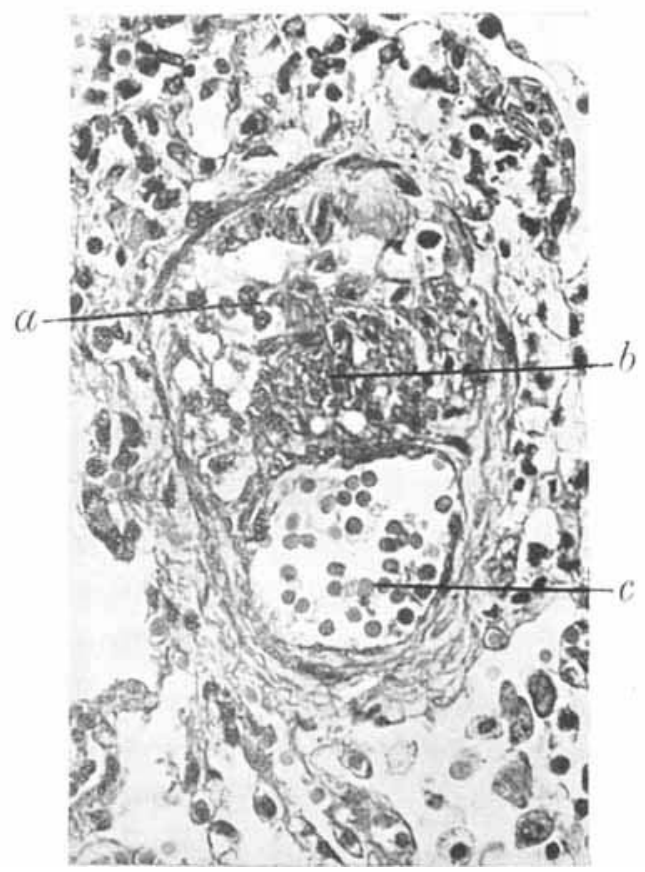

FIG. 3. 


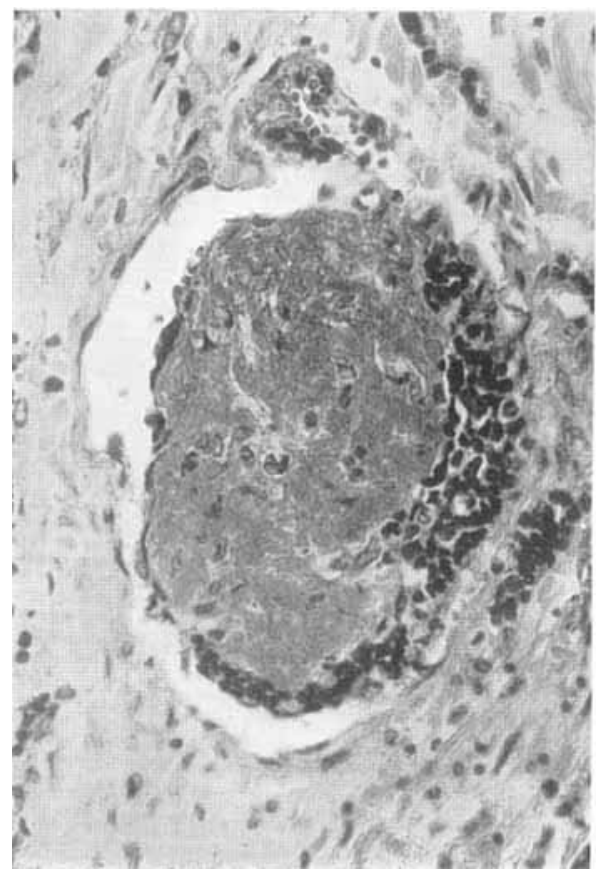

IIIG. 4.

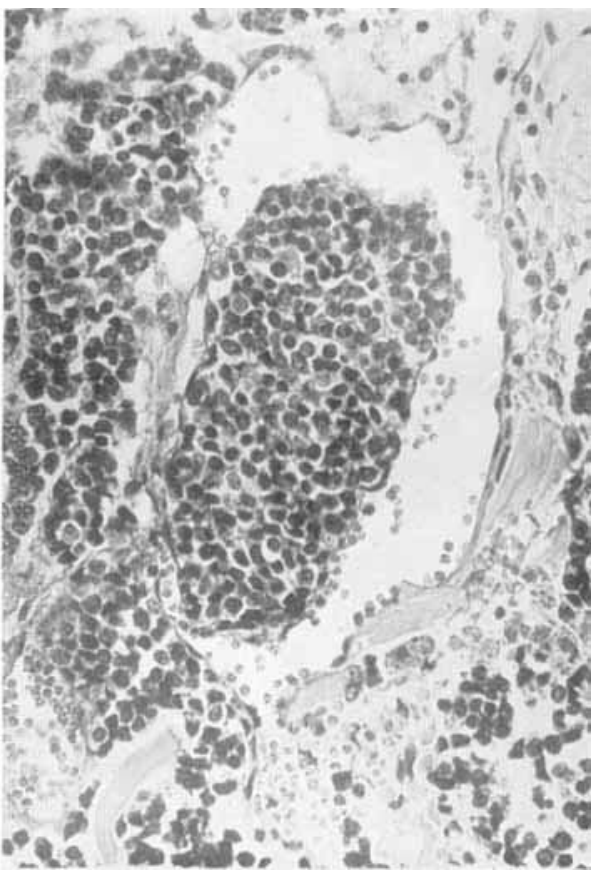

Fig. 5.

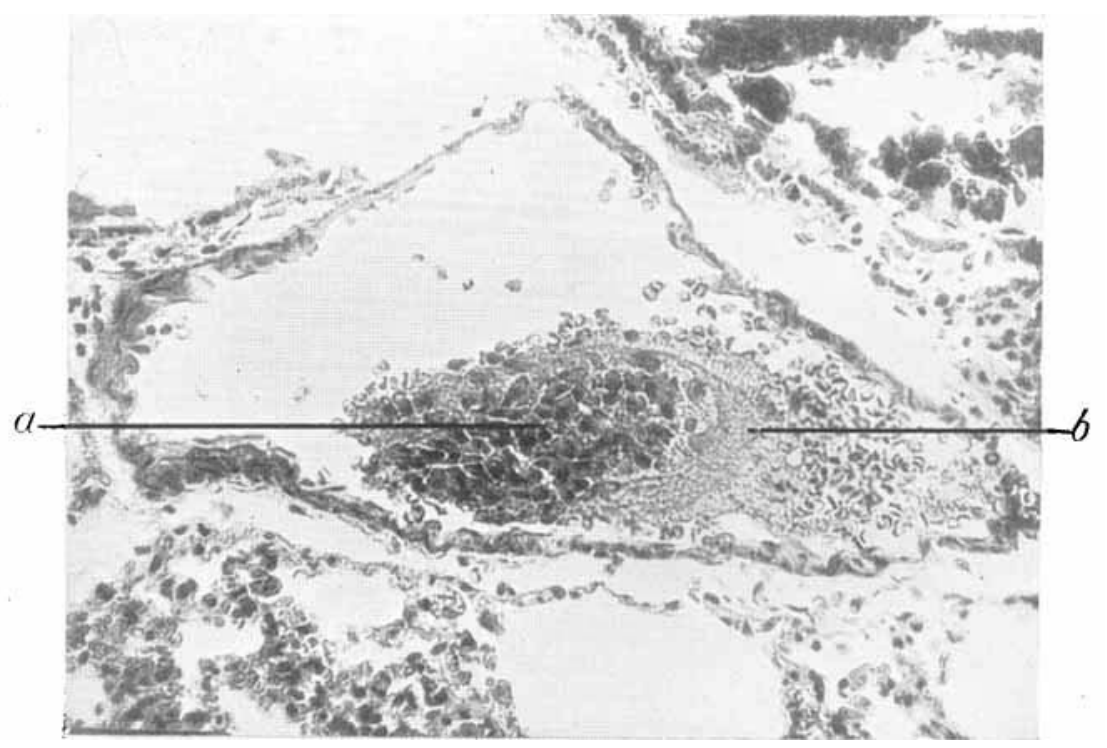




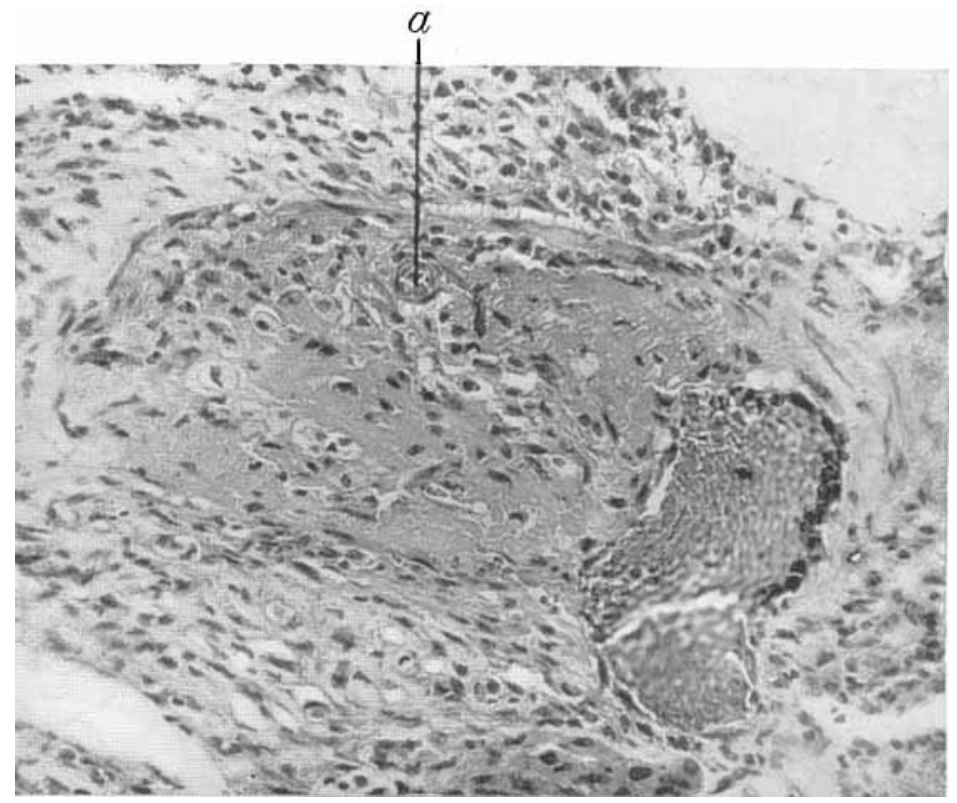

FIG. 7.
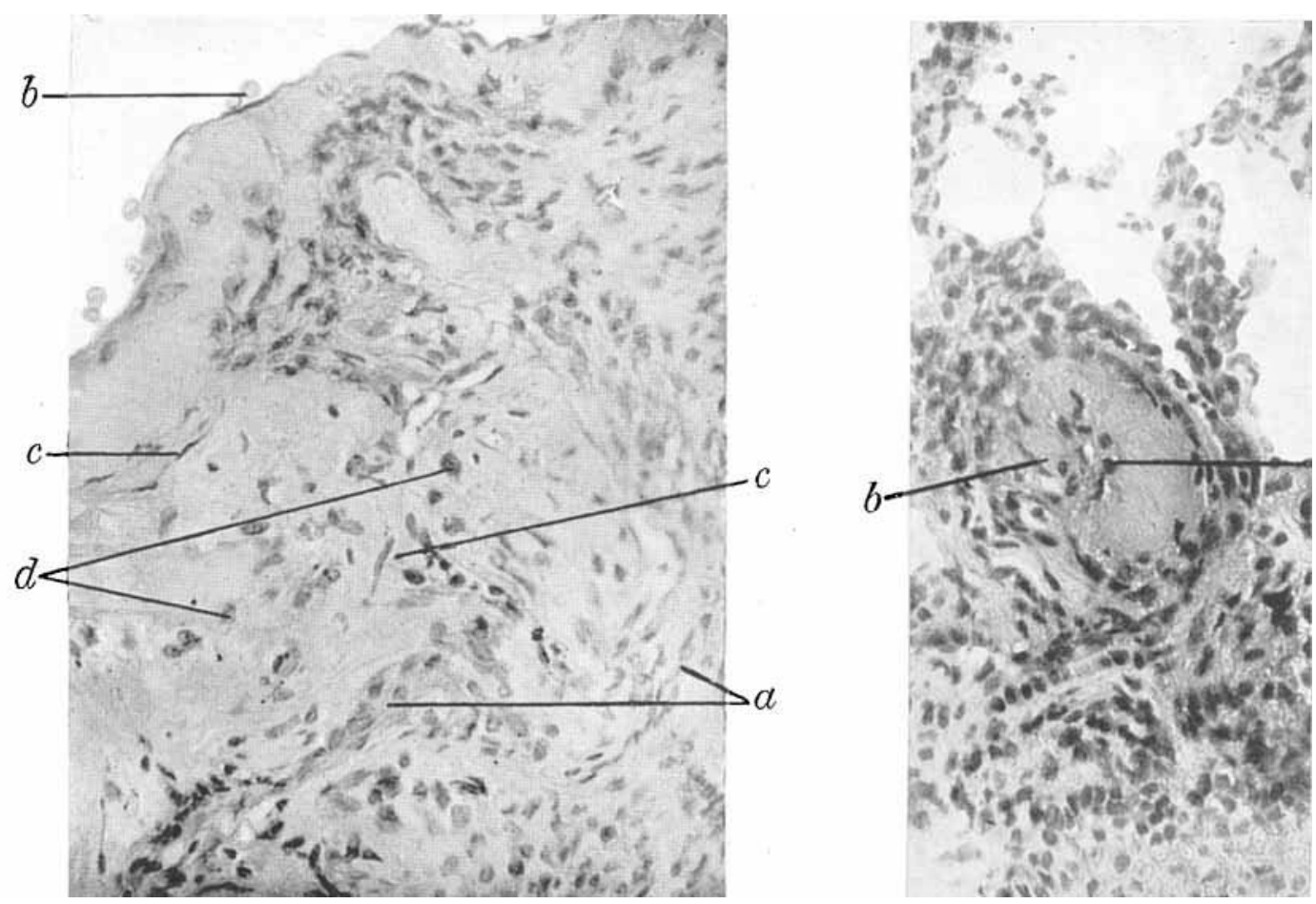

FIG. 8.

Fig. 9. 


\section{PLATE VIII.}

Frg. 4 (Case 6). -Lymphosarcoma of the mediastinum: Section of a vein from a place near the rena cava superior. A thrombus is surrounded semicircularly by a layer of growing tumour cells: the nuclei of these cells are stained very deeply, while those in the inner part of the thrombus are degenerating and lightly stained. $(\times 300$.

FIG. 5.-Another section from the same case as Fig. 4. A large tumour mass in a vessel is surrounded by a single layer of endothelium; the tumour cells look quite healthy. $(\times 300$.

FIG. 6.-Section from the lung of a rat, killed ten minutes after the injection of the sarcoma tissue. $(\times 300$.

(a) Tumour mass.

(b) Recent thrombus covering it.

Plate IX.

FIG. 7. - Section of the lung of a rat, killed thirty-four days after the injection of sarcona suspension. Connective-tissue proliferation, with a capillary $(a)$ into the thrombus and shrinkage of tumour cells are visible. $(\times 300$.

Frg. 8. - Section of the lung of a rat, killed twenty-one days after the injection of sarcoma suspension. A thrombus in artery. $(x 400$.

(a) Vessel wall.

(b) Red blood corpuscles in the lumen.

(c) Proliferated connective-tissue cells.

(d) Tumour celis embedded in the connective tissue : some are degenerated

FrG. 9.-Section of the lung of a mouse, killed seven days after the injection of mouse carcinoma suspension. $(\times 400$.

(a) Tumour cells of healthy appearance, embedded in thrombus.

(b) Connective-tissue cells. 